\title{
Luzes em Portugal: do terremoto à inauguração da estátua equestre do Reformador
}

\author{
Antonio Cesar de Almeida Santos
}

Durante muito tempo, entendeu-se que

a metáfora das "Luzes" sustentaria uma série de críticas profundas às instituições do Antigo Regime, da Monarquia Absolutista e [...] à hegemonia religiosa e cultural que o clero católico ainda exercia no interior da sociedade, advogando a necessidade de urgentes reformas políticas, educacionais, sociais. ${ }^{1}$

Essas palavras sintetizam, conforme Luiz Carlos Soares, a concepção francesa do Iluminismo, a qual acabou servindo para balizar grande parte das discussões acerca da presença das "Luzes" nos diferentes territórios europeus no século XVIII. Essa visão, no entanto, tem mudado, pois, como defendeu Franco Venturi, é fundamental considerar "a distribuição geográfica e o ritmo diferenciado do Iluminismo na Europa setecentista". ${ }^{2}$ Apesar das diferenças, a presença das "Luzes" implicou, em qualquer que fosse o lugar, "mudanças dos modelos passados e, em alguns exemplos, uma consciência de mudança mais do que um fenómeno transitório da vida humana e da história". ${ }^{3}$

Interessa-me, neste artigo, ${ }^{4}$ abordar as mudanças propostas ou realizadas durante o reinado de D. José I (1750-1777), para avaliar o conteúdo que elas manifestam. ${ }^{5}$ Pretendo, então, discutir algumas questôes sobre o que se convencionou chamar de "época pombalina", 6 na medida em esse reinado ficou muito mais marcado pela figura do marquês de Pombal - Sebastião José de Carvalho e Melo (16991782) - do que pelo próprio soberano. Nesse aspecto, estou considerando sugestão de José Sebastião da Silva Dias, para quem as "modificações introduzidas" em Portugal, a partir da segunda metade do Setecentos, além de conterem referências a ideias de intelectuais portugueses da época, apresentam elementos que deixam manifesto o contato de Carvalho e Melo "com livros e opiniōes em correlação com o ser e o agir de um estadista moderno".

O terremoto, a reconstrução de Lisboa e a inauguração da estátua equestre

A inauguração da estátua equestre, a 6 de junho de 1775, fora a apoteose do regime. Sob a figura do soberano era o ministro divinizado. [...] Através do rei, que era a sombra do poder, recebia ele [o marquês de Pombal], poder verdadeiro, as homenagens que para o outro decretara. João Lúcio de Azevedo. O marquês de Pombal e sua época, 1909.

Desde 1774, face à piora de sua saúde, D. José I havia reduzido em muito suas atividades, especialmente as aparições públicas. Contudo, o rei de Portugal não deixou de comparecer ao descerramento da estátua equestre erguida em sua homenagem, no centro da nova praça do Comércio da reconstruída cidade de Lisboa. Conforme Joaquim Veríssimo Serrão, esse foi "o derradeiro acto público" a que o soberano português esteve presente. ${ }^{8} \mathrm{Os}$ festejos do seu $61^{\circ}$ aniversário, que culminaram com a inauguração dessa estátua, em 6 de junho de 1775, foram cuidadosamente preparados sob a supervisão de José Sebastião de Carvalho e Melo que, desde 1756, ocupava o cargo de Secretário de Estado dos Negócios do Reino. Além das autoridades civis, militares e religiosas da cidade de Lisboa e arredores, comerciantes e artesãos também estiveram envolvidos nos preparativos dessa comemoração.

Diversos cronistas registraram os acontecimentos daquela ocasião e suas descrições acompanham, no geral, a de José Pedro Ferraz Gramosa, um arguto observador dos eventos que se desenvolviam à sua volta:

No dia 6 de junho de 1775, dia dos anos de Sua Majestade, expôs o Senado da Câmara de Lisboa às veneraçôes e respeito de toda a Corte a Estátua Equestre de altura colossal, cristada e laureada, que com assistência 
de dois cardeais da Igreja Romana, oito bispos, de todos os outros grandes do Reino, de todos os supremos Tribunais, das Tropas da Cidade e das praças circunvizinhas, de todos os ministros estrangeiros, e de mais de duzentos mil espectadores, dedicava na Real Praça do Comércio ao nosso Augusto Soberano. [...] Achava-se Sua Majestade com toda a Sua Real Família em uma tribuna ricamente armada nas janelas do conselho do Ultramar; e nas outras, que circundam a praça, estavam as senhoras da Corte, o corpo diplomático e os ministros dos tribunais. Honra em todos séculos, rara; em Portugal, nunca vista. ${ }^{9}$

O comerciante Jacome Ratton, outro observador do evento, destaca que este monumento foi "o primeiro erigido a Monarcas Portugueses", assinalando a "singularidade de ser tudo obra dos nacionais: invenção, desenho, modelo, fundição, condução e colocação, tudo lhes pertence, e mostram o adiantamento e perfeição a que se achavam elevadas as artes que se empregaram na formação daquele monumento". Ainda conforme Ratton, pretendeu-se "eternizar a memória deste Soberano com a Estátua", numa demonstração da "gratidão dos seus povos por tantos benefícios recebidos". ${ }^{10}$

A estátua fora instalada alguns dias antes, e seu descerramento foi realizado com toda a solenidade:

A Estátua Equestre estava coberta de alto a baixo com uma cortina de nobreza carmezim. Saiu o marquês de Pombal da Arcada debaixo da Tribuna Real vestido de capa e volta e cocar ${ }^{*}$ no chapéu; ao seu lado direito, com a mesma compostura, ia seu filho, o conde de Oeiras, presidente do Senado da Câmara, e, ao esquerdo, Anselmo José da Cruz, provedor da Junta do Comércio. Seguiam-se duas alas, a da corporação da cidade, com o conde de Oeiras, e a dos negociantes, com o seu provedor. Logo que chegaram em pouca distância da estátua, adiantou-se o marquês de Pombal e a descobriu; imediatamente a reverenciou com três cortesias de chapéu e com três mesuras, que são da etiqueta da Corte nas audiências públicas. Seguiu-se, depois de fazerem as suas reverências respeitosas as duas sobreditas alas, a prestarem suas vênias à corte e aos grandes tribunais, vestidos todos de respeito, vindo por último a tropa a fazer suas continências, terminando-se a ação com uma geral aclamação de todo aquele inumerável povo dando vivas a Sua Majestade. ${ }^{11}$

As festividades duraram três dias. A Câmara Municipal de Lisboa, a Junta do Comércio e a Casa dos Vinte e Quatro ficaram responsáveis pela realização de diferentes manifestações: baile, queima de fogos de artifício, encenação teatral, espetáculos musicais, jantares. Na tarde de 7 de junho, ocorreu um grande desfile de carros alegóricos, que representavam a América, a África, a Ásia, a Europa, Apolo, o Oceano e Portugal Triunfante:

Para fazer mais plausível e solene este festejo, fez o Juiz do Povo e Casa dos Vinte e Quatro fabricar sete carros majestosos, ornados galante e ricamente, para servirem de triunfo na celebérrima inauguração da estátua e simbolizarem a glória a que se vê elevado PORTUGAL a impulsos da beneficência do seu MONARCA. ${ }^{12}$

De certa forma, "quase tudo decorreu como previsto", apesar da informação de que o rei e a família real, ao contrário de chegarem à praça em cortejo solene, como seria o esperado, assistiram à cerimônia de descerramento da estátua "incognitamente". ${ }^{13}$ Além disso, nem tudo foi festa, pois a ocasião também esteve marcada por tensões geradas por boatos, e renderia, durante muitos anos, diversas críticas. Quanto a estas, um bom exemplo são as palavras com que Camilo Castelo Branco se referiu à efígie do marquês de Pombal, colocada na base do monumento: "pois que este escândalo de estátua me ocorreu impensadamente e quase ao concluir ao livro, farei um pequeno rol das patifarias que o marquês mandou praticar para se ver esculpido no monumento que ele a si mesmo erigia." ${ }^{14} \mathrm{O}$ principal boato anunciava que, por ocasião da inauguração da estátua, o príncipe D. José seria declarado sucessor do rei, em detrimento de sua mãe, D. Maria. Contudo, não houve "o juramento do príncipe da Beira", nem o propalado anúncio de seu casamento com a infanta D. Maria Francisca Benedita, sua tia. ${ }^{15}$

Apesar dos percalços, a ocasião marcou, definitivamente, aquele reinado. José-Augusto França, o principal estudioso da "Lisboa pombalina", ${ }^{16}$ defende que a estátua coroou "toda a imensa obra da Reconstrução, homenageando o príncipe reinante e, ao mesmo tempo, o seu ministro, cuja efígie figura no pedestal”. Ainda conforme França, a ideia de construção da estátua datava de "1759, ou antes", mas sua execução ficou aguardando que as ruínas da cidade dessem lugar a um cenário mais propício. ${ }^{17}$ 
Grande parte da cidade de Lisboa, especialmente sua área central, havia sofrido as consequências do terremoto, dos diversos incêndios e das grandes ondas que avançaram Tejo adentro, no dia primeiro de novembro de 1755 .

Quando o abalo se suspendeu, os lisboetas ficaram atarantados pela cidade, perdidos uns dos outros. [...] O grande pânico dos incêndios ocorreria passado umas horas. Para já, os lisboetas parecem ter pensado que o pior tinha passado - se é que conseguiam pensar em alguma coisa. [...] Apesar de tudo, quando a onda gigante chegou à capital do Reino tinha ainda seis metros de altura, o que foi suficiente para causar estragos consideráveis. ${ }^{18}$

Muitas residências, inclusive de membros da nobreza, prédios públicos e comerciais e igrejas desabaram ou arderam naquele dia e nos seguintes. O Paço Real, a Igreja Patriarcal, o Palácio da Inquisição e o recente Real Teatro da Ópera ficaram em ruínas. Muitos outros edifícios foram derrubados nos dias e meses subsequentes.

Um informador da época, relativamente fidedigno, calculou que dez por cento das 20.000 casas da cidade ficaram destruídas e mais de dois terços delas inabitáveis. Dos 72 conventos e recolhimentos só 12 podiam servir sem perigo maior, após a catástrofe, à qual nenhum dos seis hospitais escapou e que destruiu ainda 33 palácios das maiores famílias da Corte [...]. A parte da cidade mais sacrificada era também a mais densamente habitada, na baixa central, na encosta ocidental do Castelo [de São Jorge] e na zona oriental do bairro Alto, o terço da sua área central $\left[\ldots . .{ }^{19}\right.$

Quanto às vítimas fatais, "uns dizem que foram quinze mil os mortos; outros, vinte e quatro mil; outros, setenta mil. Perda foi esta que não se poderá calcular tão facilmente” ${ }^{20}$ De fato, segundo Kenneth Maxwell, "as estimativas do número de mortos variaram de dez mil a quarenta mil (na época todos acreditavam amplamente nesta última cifra, se bem que o número real deva beirar os quinze mil)". ${ }^{21}$ Esta cifra, porém, ainda é controversa, como aponta José-Augusto França:

[...] o número de mortos e dos feridos cresceu de boca em boca. O Núncio calculou quarenta mil mortos, outros falavam em setenta ou noventa mil, o futuro marquês de Pombal reduziu o cálculo a seis ou oito mil - mas os números mais fidedignos da época anunciam de doze a quinze mil, e, finalmente, concluiu-se terem perecido uns dez mil habitantes, em plena catástrofe ou por seu efeito. ${ }^{22}$

A reconstrução da parte destruída da cidade de Lisboa não foi imediata, e demandou uma série de providências para se proceder à limpeza das ruas e terrenos e, depois, ao levantamento dos novos edifícios. $^{23}$ Em 12 de maio de 1758, por meio de um Alvará, D. José I determinou a "reedificação" da cidade, a qual deveria atender a um "novo plano regular e decoroso", que previa ruas alinhadas com "a retidão e largura competentes à comodidade de seus habitantes e ao serviço dos que por elas passam". Os antigos proprietários que quisessem reconstruir suas moradias ou lojas deveriam seguir o "sobredito plano" e levantarem os novos prédios num prazo de cinco anos. ${ }^{24}$

Em linhas gerais, os responsáveis pelo "novo plano regular e decoroso" preservaram as praças e os largos existentes, ao mesmo tempo em que diversas ruas "estreitas e tortuosas" foram alargadas e tiveram seus traçados refeitos, endireitando-as. As ruas também receberam "os necessários e utilíssimos passeios", para a comodidade dos transeuntes, "mas o que é imperdoável nesta nova reedificação é que todas as ruas não tenham, e todas as casas, cloacas, para o despejo das primeiras imundícies”. Com essas palavras, Jácome Ratton, não obstante celebrar a "reedificação da cidade de Lisboa" como uma das maiores obras do reinado de D. José I, atestava que, se não fossem tomadas providências para a melhoria do quadro sanitário,

a fedorenta cidade de Lisboa será sempre um manancial de moléstias, a vergonha da Nação e um objeto asqueroso, pelos montóes de imundícies acumuladas nas ruas, por efeito do descuido inveterado de se não varrerem e se não tirarem [as sujeiras] com a devida regularidade, não obstante as rendas que há destinadas para isso. ${ }^{25}$ 
Embora os trabalhos de reconstrução da cidade tenham se iniciado a partir do Alvará de 12 de maio de 1758, a Praça do Comércio ainda estava por terminar, na data de inauguração da estátua: alguns painéis com fachadas pintadas cobriam "o que faltava por acabar" ${ }^{26}$ Porém, não obstante essa situação, José-Augusto França, como apontado acima, afirma que a nova praça, que substituiu o antigo Terreiro do Paço, "nobilita todo o plano da Reconstrução":

As suas arcarias regulares, o arco do triunfo que dá acesso à cidade (só terminado, com outro desenho, cem anos mais tarde), a estátua equestre do rei D. José, por Machado de Castro (1775), primeiro monumento significativo que Lisboa teve, formulam uma nova Place Royale de gosto internacional que o nome imposto contraria, sociologicamente. ${ }^{27}$

Também para Kenneth Maxwell, a nova denominação daquele espaço é significativa, na medida em que a cidade "deveria ser um centro eminentemente comercial e administrativo. [...] O planejamento urbano e arquitetônico de Pombal objetivava celebrar a independência econômica e nacional e um Estado moderno, bem-regulado e utilitário". ${ }^{28}$

Alguns intelectuais da época, como o padre António Pereira de Figueiredo, reputado como "um dos mais emblemáticos teóricos da política regalista pombalina”, ${ }^{29}$ atribuíram significado semelhante à estátua equestre de $\mathrm{D}$. José $\mathrm{I}$, considerando-a como um monumento à memória das diversas realizaçóes daquele reinado. ${ }^{30}$ Para Joaquim Machado de Castro, o escultor responsável pela execução do monumento,

o terremoto fatal que Lisboa sofreu no primeiro de novembro de 1755, sendo causa de muitos desastres para este Reino, também lhe abriu caminho para algumas felicidades, como têm julgado bons políticos. Uma das consequências daquele espantoso fenômeno foi a reedificação desta capital, muito mais cômoda e mais bela do que era antigamente. Cometeu-se o projeto desta grande obra ao capitão Eugenio dos Santos, arquiteto civil e militar, e designou-se ao mesmo tempo erigir uma estátua equestre no centro da nova praça do Comércio, em obséquio do Senhor Rei D. José I, Pai da Pátria, Augusto Restaurador da Metrópole e de tantos bens Patrióticos. Lembrança não só feliz, mas, por todos os motivos, digna de muitos louvores. ${ }^{31}$

O mesmo escultor, ao defender a importância de seu trabalho, afirmava que "todas as nações polidas e cultas, desde o tempo da florente Grécia, até o século em que vivemos, se empenharam, com digno louvor, em erigir estátuas"; muitas delas especialmente dedicadas "ao nome e glória de soberanos", na medida em que "a ventura de seus povos" depende "das sábias deliberaçôes" desses homens. ${ }^{32}$

O rei D. José I, contudo, não fora um entusiasta da execução da estátua, chegando mesmo a recusar-se a posar para Machado de Castro. ${ }^{33}$ Porém, em que pese essa postura do soberano, foram muitas as manifestações de júbilo em torno da inauguração desse imponente monumento. Em Paris, António Nunes Ribeiro Sanches, em meados de outubro de 1775, escreveu nas páginas de seu diário um soneto dedicado "a Sua Majestade Fidelíssima na inauguração da estátua equestre". Inspirando-se nos heróis "gregos e latinos", um agradecido Ribeiro Sanches saudava "o Pio, o Sábio, o Forte, o Justo Monarca Lusitano, cuja História faz esquecer a do famoso Augusto. Lusitânia feliz, é tua a glória: ergue a cabeça, vê subir sem susto teu Rei ao Templo da imortal memória". ${ }^{44}$

Na mesma ocasião em que a estátua era descoberta, diversos papéis circularam em Lisboa com todo o tipo de versos em homenagem ao "dia feliz da inauguração do colosso real", como José Basílio de Magalhães intitulou um de seus sonetos. ${ }^{35}$ A Casa dos Vinte e Quatro também publicou e fez declamar diversos poemas em homenagem ao soberano.

Soneto (para recitar o terceiro Deputado)

Com estrela feliz, faustos auspícios

A Estátua se levante ao REI Clemente,

Por quem ergue Lisboa a altiva frente

Ornada de soberbos edifícios. 
São tênues os votivos sacrifícios,

Que grata lhe tributa a Lusa Gente.

Mas quais serão, por mais e mais quem invente

Dignos de compensar seus benefícios?

Fiando pouco da inconstante História,

Porque vença dos Tempos o destroço,

Lhe esculpimos em bronze a Memória.

Mas ainda erigindo este Colosso,

Se tem nisso a Nação a maior glória,

O mesmo obséquio é só proveito nosso. ${ }^{36}$

O padre António Pereira de Figueiredo, aliás, fazia questão de destacar "as eruditas composições que em prosa e verso se publicaram" por ocasião "da solene inauguração da estátua equestre de Sua Majestade", exaltando também as ações do marquês de Pombal, "este grande homem, ou por falar com toda a propriedade, este herói", a quem o soberano havia franqueado "toda a entrada não só do Gabinete, mas também do seu régio coração". ${ }^{37}$

Não obstante todos os elogios e tantas celebrações, após a morte do rei e de o marquês de Pombal ter caído em desgraça, o episódio da inauguração da estátua equestre passou a ser inspiração para a composição de várias folhas satíricas, todas atingindo diretamente o marquês, mas preservando a figura de D. José I, ${ }^{38}$ cognominado o Reformador.

O apogeu antes da queda

Pois que dados os princípios que a economia do Estado e a aritmética política estabeleceram, para que por eles se possa formar uma completa ideia do estado da civilidade, da política, da opulência e das forças de qualquer nação culta, seus efeitos viram-se aparecer em público com esta faustosíssima ocasiāo, na Corte de Lisboa, causando assombro a todos os nacionais e estrangeiros. Sebastiāo José de Carvalho Melo. Memórias secretíssimas do marquês de Pombal e outros escritos. s.d.

Em trabalho anterior, já havia indicado que o marquês de Pombal aproveitara-se da inauguração da estátua equestre para fazer a celebração das reformas até então realizadas (ou, ao menos, idealizadas). ${ }^{39}$ Conforme suas palavras, ele próprio entregou ao seu soberano o texto que proclamava essa reforma e que recebeu dos pósteros o nome de Observaçōes secretíssimas do Marquês de Pombal, Sebastiāo José de Carvalho e Melo, na ocasião da inauguração da Estátua Equestre no dia 6 de junho de 1775, e entregues por ele mesmo oito dias depois ao senhor rei D. José I..$^{40}$

O texto em questão é uma apologia às ações de governo que, segundo o marquês de Pombal, teriam "inteiramente dissipado e reparado as trevas e ruínas em que [D. José I] achou sepultados os seus Reinos". Todas as ações - propostas ou realizadas - teriam confluído no sentido de proporcionar um estado geral de "opulência" ao Reino, estendida a todos os vassalos portugueses. As mesmas "iluminadas e providentes resoluções" também foram responsáveis por elevar Portugal ao mesmo patamar das demais nações europeias que, "com arrogância, vanglória e superioridade olhavam antes para a portuguesa como bisonha, rude, inerte e destituída de todos os elementos e princípios das artes fabris e liberais e dos verdadeiros conhecimentos das ciências maiores”. Mas, o maior resultado alcançado pelas determinações baixadas "do real trono de Sua Majestade" foi o de mostrar que "a estimação nacional está inteiramente restabelecida". ${ }^{41}$

As "observações" do marquês de Pombal estão organizadas em duas partes distintas e interligadas; na primeira, ele expõe os "princípios" que orientaram as mudanças necessárias para reparar a ruína em que se achava o império português. Como se sabe, esse estado de calamidade era atribuído, principal- 
mente, à ação dos religiosos da Companhia de Jesus, a qual foi expulsa dos domínios portugueses em $1759 .{ }^{42}$ A segunda parte do texto apresenta os "efeitos" decorrentes das providências adotadas.

Nuno Monteiro, ao também voltar sua atenção para as Observações secretíssimas..., sugere que elas permitem vislumbrar

[...] duas notórias "novidades": o facto de se multiplicarem as "providências" e de estas partirem de um "ministério", isto é, de um governo. Mas há ainda outra novidade essencial: legisla-se para modificar o que existe. O bom governo já não se rege apenas pelo objectivo de "fazer justiça", de pôr as coisas no seu lugar. Procura-se agora mudar as coisas, em conformidade com o que se fazia nas "cortes da Europa". ${ }^{3}$

Considerando o desejo de "modificar o que existe", esse texto pombalino mostra que o "governo" adotou medidas com os objetivos de: a) fomentar uma boa caligrafia, capacitando pessoas para trabalharem nas "contadorias do real erário, das juntas da fazenda e do comércio, das companhias gerais e das outras repartiçōes públicas"; b) desenvolver as "artes fabris ou ofícios mecânicos, que são os braços e as mãos de todos os estados"; c) proteger e animar as "artes liberais", de que eram exemplos, entre outros tantos, os "suntuosos e bem delineados edifícios de Lisboa" e a "portentosa estátua equestre e o soberbo e delicado pedestal dela"; d) promover o cultivo da "filosofia ou das belas-artes, que servem de base a todas as ciências"; e) incitar o desenvolvimento das "ciências maiores", consubstanciado na reforma dos Estatutos da Universidade de Coimbra; f) garantir o crescimento do comércio interno e externo tornando-o "mais feliz e opulento do que foi naquele século dos senhores reis D. Manuel e D. João III"; g) assegurar a harmonia entre os "diferentes estados e entre as ordens, classes e grêmios" que compunham a sociedade portuguesa; h) garantir "o estado de opulência dos vassalos" de D. José I. ${ }^{44}$

Segundo o marquês de Pombal, essas anunciadas ações geraram um conjunto de resultados que podiam ser observados por toda parte: os novos estatutos da Universidade de Coimbra eram invejados por outras nações, assim como "as leis e resoluções de Sua Majestade"; no que respeita ao comércio, "em nenhuma outra Corte da Europa se ensinou até agora o mesmo comércio por princípio”, com a criação da Aula de Comércio, em 1759; quanto ao estado de civilidade da nação portuguesa, os estrangeiros, que sempre a reputaram "por bárbara, feroz e insociável", viram-se "a este respeito, não só igualadas, mas muito excedidas", considerando que a aglomeração de "mais de cento e cinquenta mil pessoas de ambos os sexos da ínfima plebe e espécie do povo miúdo em confusão e aperto na Praça Real do Comércio" não havia provocado nenhum distúrbio e, ao contrário, todos se comportaram "com a mesma tranquilidade e silêncio, como que poderiam estar em uma igreja fazendo oração". ${ }^{45}$

A imagem que as outras cortes europeias faziam dos portugueses não era, propriamente, positiva. Conforme Maria Antónia Lopes, "Portugal era representado nos países mais ricos como uma nação exótica e bárbara e os viajantes, munidos dessa ideia feita, procuravam certamente confirmar o que pensavam e transmitir aos leitores informaçôes curiosas com valor comercial”. ${ }^{46}$ Castelo-Branco Chaves, em seu prefácio às descrições de Portugal feitas por "três forasteiros", lembra que "a vida social portuguesa descrita por estes viajantes estrangeiros não aparece brilhante, chegando mesmo a parecer soturna". ${ }^{47}$ Essa avaliação é corroborada, por exemplo, por César de Saussure que, em uma de suas "cartas escritas de Lisboa no ano de 1730", divulgava a seguinte informação:

A princesa D. Francisca, irmã do rei, acompanha também frequentemente a rainha nas suas saídas. Terá uns trinta anos, é muito bela, bastante graciosa mas está um pouco gorda. Rosna-se que não é feliz e vive sob uma espécie de sequestro, guardada à vista e debaixo de chaves desde que revelou possuir um coração terno e manifestou preferência por um certo fidalgo da embaixada de Espanha. O pobre homem pagou cara a honra de ter agradado à princesa, pois pouco tempo depois da descoberta destes amores foi encontrado morto numa rua. ${ }^{48}$

Esse tipo de comentário, em que se procurava retratar uma aludida ferocidade dos portugueses não cessou depois de D. José I ter subido ao trono, apesar de Maria Antónia Lopes apontar que, desde o ter- 
remoto, teria ocorrido uma "liberalização dos comportamentos", também incentivada pela "influência estrangeira". ${ }^{49}$ De todo modo, para Giuseppe Gorani, a insociabilidade dos portugueses era encontrada especialmente junto aos governantes.

Após a prisão, o Rei nomeou uma comissão para julgar o coronel e o regimento [dos Reais Estrangeiros]. Os oficiais que a compunham não conheciam as verdadeiras intenções do Conde de Oeiras e depois de, com boa fé, terem examinado culpas e provas, ouvido os acusadores e as testemunhas, bem como as respostas dos presos, consideraram a culpa como não existente. O ministro ficou irritadíssimo contra a comissão; suprimiu-a, anulou as sentenças e declarou seus membros incompetentes para o serviço do Rei. [...] foi desde então que, constatando a iniquidade deste governo, me arrependi de ter vindo tentar fortuna nesta cloaca de perversidade $!^{50}$

Castelo-Branco Chaves, que editou as memórias de Gorani em português, assinala que "inverosimilhanças, erros e mentiras existem, de facto, como o leitor verificará por si ou auxiliado pelas notas"; em uma dessas notas, referente ao episódio acima mencionado, é apresentado um trecho de carta do enviado francês em Portugal, o conde de Saint-Priest:

Houve justa indignação ao ver o conde de Oeiras, mal saído das portas da morte, aproveitar os primeiros momentos que teve para se avistar com o Rei seu senhor, para lhe arrancar a execução de uma sentença iníqua dada por juízes cobardes a fim de satisfazerem o ódio do Ministro contra este oficial. Nem uma só peça de acusação teria validade em França. O Conde de Oeiras tem um coração de bronze e uma alma impiedosa. ${ }^{51}$

Como se percebe, não eram apenas os viajantes que construíam a imagem de Portugal como uma nação "feroz e insociável". A correspondência diplomática também era utilizada para caracterizar o estado de incivilidade (ou de barbárie) dos portugueses, especialmente daqueles que ocupavam postos de governo.

Nesse sentido, ao apontar os desejados "efeitos" das "paternais, magnânimas e infatigáveis providências" de D. José I, o marquês de Pombal fazia questão de emular a situação portuguesa à de outras nações europeias, especialmente França e Inglaterra. Mas não foram apenas questôes sociais e econômicas que receberam a sua atenção; a contraposição da situação política de Portugal aos demais estados europeus é, afinal, um objetivo bem demarcado em sua minuciosa exposição.

Quando a consistência do governo da maior parte das cortes da Europa se acha enervada e enfraquecida, ou com discórdias e divisões intestinas, como está sucedendo em França e Inglaterra, ou com sediçōes clandestinas e cizânias brotadas pelas venenosas raízes jesuítas, que não puderam arrancar até agora, como está sucedendo em Espanha, Sabóia, Roma e grande parte de Itália e Alemanha. Depois de terem visto os estrangeiros, pelo contrário, que em todo o Portugal e seus domínios, não soam outras razões que não sejam as que baixam do real trono de Sua Majestade, que deles são ouvidas com suma reverência, por se acharem os vassalos do mesmo senhor constituídos na firmíssima fé de que só ele resolve e determina o que é mais útil aos seus vassalos e de que a todos os ama e ampara como a filhos, e não como a súditos. ${ }^{52}$

Os exageros do marquês devem ser matizados, mesmo porque o "governo" - na acepção de Nuno Monteiro - precisara valer-se de algumas açôes espetaculares para inculcar nos vassalos portugueses de todos os diferentes estados, "ordens, classes e grêmios" algumas noções de civilidade, harmonia e amor filial. Em 1775, ainda era recente a lembrança dos resultados do atentado sofrido por D. José I, no qual foram implicados representantes da fidalguia portuguesa, o duque de Aveiro e os marqueses de Távora e seus familiares. Como assinalou Joaquim Veríssimo Serrão, repercutiu em toda a Europa

[...] a cena atroz do suplício de Belém, onde na madrugada de 13 de janeiro [de 1759] os réus foram conduzidos para a execução da sentença. [...] Tudo se processou com inaudita violência, como se a justiça régia buscasse extrair uma lição para quantos ousassem atentar contra a vida do soberano. ${ }^{53}$

Outros acontecimentos também serviram para conduzir a população do Reino (e a dos demais domínios portugueses) à tão desejada civilidade, como o processo de expulsão dos jesuítas, a prisão e 
execução do padre Gabriel Malagrida e a repressão à "rebelião" dos comerciantes do Porto, em 1757, que se amotinaram contra o monopólio concedido à Companhia das Vinhas do Alto Douro para a comercialização do vinho. Nesse caso, a condenação de 13 homens e 5 mulheres à pena de morte, além de outras tantas penas de degredo para a África, foi assim justificada:

A rebelião de grande parte da plebe de uma cidade, que depois da Corte é sem disputa a maior e mais opulenta desta monarquia, foi um dos casos mais estranhos do presente século; especialmente porque a toda nação portuguesa causa horror o menor movimento, que possa parecer infidelidade ao seu soberano, a quem os súditos respeitam, mais com amor de filhos que de vassalos. ${ }^{54}$

Além destes casos, as medidas de exceção tomadas após a ocorrência do terremoto e na reconstrução de Lisboa também serviram para demonstrar o alcance das "infatigáveis providências" adotadas durante o reinado de D. José I.

Esperava-se ainda que as "resoluções de Sua Majestade" conduzissem seus vassalos a uma situação de riqueza material, o que seria benéfico aos indivíduos e ao próprio Reino. Essa expectativa estava relacionada à percepção de que Portugal, em meados do século XVIII, enfrentava uma séria crise comercial, ainda que seus cofres estivessem lastreados pelo ouro e diamantes extraídos do Brasil. Conforme Kenneth Maxwell, durante toda a primeira metade daquele século, "o comércio apresentava-se largamente a favor da Grã-Bretanha” e o grande afluxo de ouro do Brasil "exagerou o desequilíbrio na balança comercial anglo-portuguesa", atingindo o desenvolvimento da atividade manufatureira e mantendo Portugal na condição de "um importador de cereal crônico". 55

Em relação à situação econômica, o marquês de Pombal destacava que, "quando antes, tudo o que eles costumavam fabricar entrava pela barra, vindo dos reinos estrangeiros, se viu agora quanto as manufaturas nacionais florescem. [...] porque até os espelhos, placas e vidros de beber foram feitos nas fábricas do Reino por vassalos de Sua Majestade" ${ }^{56}$ Em relação à instalação de fábricas e outros estabelecimentos manufatureiros, Armando de Castro, em clássico estudo sobre a "política econômica" do período, refere-se ao texto "Quinta inspeção: sobre o estabelecimento das artes fabris e manufactureiras", redigido por Carvalho e Melo já em seu exílio da Corte. Nesse texto, foram mencionadas "múltiplas indústrias criadas ou desenvolvidas" no reinado de D. José I. Para além de uma extensa lista de estabelecimentos, anuncia-se que, com a instalação de fábricas de tecidos, quase cessaram "as importações de panos ingleses". Armando de Castro aponta que

[...] poderia adicionar-se o esforço no artesanato de cutelaria, relojoaria, fundição de metais, o revigoramento da Real Fábrica das Sedas do Rato, cambraias, pelica e pele, grude; destacar-se a Fábrica de Vidros da Marinha Grande de Guilherme Stephens, óleo de peixe em Aveiro e Ovar, lonas, enxárcias, tapeçarias em Tavira... Tudo isto é conhecido. ${ }^{57}$

Para Nuno Monteiro, ainda que o fomento à atividade de manufatura fosse bem anterior "à adopção de uma política mais sistemática de promoção", as iniciativas diretamente patrocinadas ou beneficiadas por medidas de governo, no reinado de D. José I, "representaram uma ampliação sem precedentes do tecido industrial português", ainda que sua continuidade não tenha sido assegurada. ${ }^{58}$ Nesse aspecto, Armando de Castro já havia apontado que o esforço manufatureiro e fabril realizado na segunda metade do século XVIII foi o responsável pela "formação duma certa mão de obra especializada e a fixação de algumas instalações industriais de tipo artesanal e manufactureiro que subsistiram depois", ressalvando, entretanto, que essa situação não pode ser entendida como a base "daquilo que haveria de ser a 'industrialização possível' do século XIX" ${ }^{59}$

Ainda em relação ao desenvolvimento da atividade fabril e manufatureira em Portugal, Rômulo de Carvalho destacou a importância de diversos estrangeiros "que foram procurados pelos serviços do estado, ou por estes aceites por oferecimento dos próprios interessados, que dirigiram fábricas e oficinas, ou nelas trabalharam". A extensa lista apresentada, da qual foram excluídos "casos insuficiente- 
mente definidos", além de "tornar bem sensível a participação dos estrangeiros no plano de animação industrial", ${ }^{60}$ corrobora, a meu ver, a adoção de providências que visaram ao fomento das "artes fabris ou ofícios mecânicos, que são os braços e as mãos de todos os estados”.

A importância e os resultados do incentivo à indústria também podem ser indicados, como aponta Nuno Monteiro, "pela quebra das exportações inglesas para Portugal”, a partir da década de 1760, quando ocorre uma redução "nas importaçôes de produtos manufacturados ingleses, e o abastecimento de cereais a Portugal pelos ingleses sofre um decréscimo assinalável, ao ponto de quase desaparecer no fim da década. Outros fornecedores de pão entraram então em cena". ${ }^{61}$

Como acima indicado, as "infatigáveis providências" de Sua Majestade, D. José I, ocuparam-se de muitos outros assuntos. Contudo, não deixa de ser estranho a ausência nas Observaçôes secretíssimas... de qualquer comentário sobre o estado da agricultura em Portugal, ${ }^{62}$ pois, como explica José Vicente Serrão,

O problema maior do sector cerealícola, principalmente no que respeita ao trigo, começava por ser o facto de Portugal não ter condições edafo-climáticas muito favoráveis para a sua cultura. Ao que acresciam outros problemas, ligados às condições técnicas e socioeconómicas da produção, às más condições de circulação, às barreiras legais a essa circulação etc. Todos esses problemas, conjugados, criavam uma situação que se caracterizava principalmente por duas coisas. Em primeiro lugar, por um défice nacional de cereais [...]. Em segundo lugar, pelo facto de, nos mercados em que se confrontavam, os cereais importados conseguirem apresentar preços inferiores aos nacionais. ${ }^{63}$

Os responsáveis pelo governo no reinado de D. José I pareciam ter completa ciência dessa situação, pois entendiam que "as riquezas essenciais de todos os povos" derivavam do que produzia "a lavoura e a indústria dos habitantes deles, devendo por isso animar-se a primeira e favorecer-se a segunda”. ${ }^{64}$ Esse entendimento é corroborado, por exemplo, pela concessão aos "lavradores do Alentejo, que cultivavam terras de comunidades ou de particulares, as mesmas providências já auferidas pelos agricultores da Casa de Bragança e das comendas das Ordens militares”. No preâmbulo do Alvará de 1774, que instituía essa mudança afirmava-se que essa decisão decorria por se considerar "a Agricultura uma das quatro colunas, que sustentam o Estado político; e os frutos da terra os elementos das Artes, da Indústria e as bases do Comércio". ${ }^{65}$

Conforme António Pereira de Figueiredo, D. José I “cuidou em que não houvesse mingua dos provimentos de que necessita a vida humana, e em que as terras se cultivem" . "Sabe-se, a propósito, que, na época, foi realizado "um inventário das terras" no Reino, para se saber quais se achavam cultivadas, as que estavam incultas, o que as terras produziam e o que seria possível produzir, se exploradas. ${ }^{67}$ Especificamente em relação à exploração da terra, Armando de Castro assinalou que, na segunda metade do Setecentos, "acentuam-se providências pontuais de libertação da terra e de desbloqueamento da circulação agro-pecuária", com a adoção de medidas que possibilitavam a "passagem de baldios à posse particular" e proibiam a "existência de pastos comuns" em algumas regiōes; contudo, foram "medidas de tímida libertação das peias feudais sobre a terra, que avançaram ainda com a extinção das pequenas capelas em 1788 " ${ }^{68}$

Outras tantas ações de governo marcaram o reinado daquele que, segundo o marquês de Pombal,

[...] não só tem inteiramente dissipado as trevas e reparado as ruínas em que achou sepultados os seus reinos, mas que, além disso, tem feito aparecer outra vez em Portugal o século feliz dos senhores reis D. Manuel e D. João III, para os exceder com os progressos das suas paternais, magnânimas e infatigáveis providências. ${ }^{69}$

D. José I, porém, "não sobreviveu muito a tamanha glória".70 


\title{
As Luzes, o Reformador e o déspota
}

\begin{abstract}
Antônio Ribeiro dos Santos, durante um periodo de autocritica após a morte de Pombal, resumiu o paradoxo do autoritarismo e do iluminismo de Pombal do seguinte modo: "[Pombal] quis civilizar a nação e, ao mesmo tempo, elevar o poder real do despotismo." Este paradoxo, comum entre os absolutistas europeus do século XVIII mas que encontra talvez o seu exemplo mais extremo em Portugal, é o tema deste livro. Kenneth Maxwell. Marquês de Pombal: paradoxo do Iluminismo. 1996.
\end{abstract}

Menos de dois anos após a inauguração da estátua equestre de D. José I, na nova Praça do Comércio, em Lisboa, faleceu aquele que, como registra Nuno Monteiro, "por reformador ficou cognominado na posteridade contemporânea, em resultado das muitas reformas que então se fizeram e proclamaram", e que foram afirmadas "de várias maneiras e em muitos textos" ${ }^{71} \mathrm{Um}$ dos registros mais notáveis é, sem dúvida, o texto apresentado acima, no qual Sebastião José de Carvalho e Melo aponta as "muitas reformas" tidas como realizadas, ainda que essas suas conhecidas "observaçôes", estejam marcadas pela parcialidade e autocelebração.

Além do objetivo de demonstrar que o desenvolvimento das "artes fabris e liberais" em Portugal havia se igualado ao das outras nações europeias, e que, "nas ciências maiores", excedia a muitas delas, "como os italianos e franceses não têm já feito cerimónia de confessar muitas e repetidas vezes", ${ }^{72}$ o marquês de Pombal expressou o desejo de, com as suas Observaçôes secretíssimas..., assegurar a "prosperidade do Reino", dando continuidade ao modo de governar então adotado.

Devo, ultimamente, protestar que não foi a vaidade, que nunca tive, a que me deu motivo para escrever estas observaçōes; porque na prosperidade do Reino que elas manifestam, e no gloriosíssimo governo a que elas se devem, reconheço que não tive algum merecimento; mas sim, e tão somente a incomparável fortuna de Sua Majestade haver confiado da minha fidelidade, zelo e amor ao seu real serviço, a execução das suas iluminadas e providentes resoluções e ordens, sendo, aliás, o meu único objecto deixá-las escritas aos meus sucessores para recomendação do exatíssimo cuidado com que devem conservar tudo o que o dito senhor tem estabelecido no seu felicíssimo reinado; porque enquanto se governarem pelos mesmos princípios e pelas mesmas máximas, é certo que terão sempre os mesmos felicíssimos sucessos, fugindo às novidades com que ordinariamente costumam, os que entram de novo, querer emendar o que está bem para que esteja melhor, quando a experiência tem demonstrado que semelhantes novadores, em lugar de conseguirem o que cuidam, que é melhor, arruínam assim o que estava bem com irreparáveis ruínas da coroa a que servem e aos vassalos dela. ${ }^{73}$

Apesar de longa, a citação acima traz algumas questões que precisam ser exploradas, se se quiser entender o contexto e o significado das reformas então anunciadas e a prática política que caracterizou o reinado de D. José I. Em primeiro lugar, deve-se considerar que, para Carvalho e Melo, o modo de governar adotado fora o responsável pela desejada prosperidade do Reino; que o governo, por sua vez, derivava das "iluminadas e providentes resoluçôes e ordens" baixadas desde o trono; e, que as "paternais, magnânimas e infatigáveis providências" estavam amparadas por "princípios" que deveriam, no futuro, ser seguidos por aqueles que estivessem encarregados do governo. Esses princípios, referidos no início das Observaçôes secretíssimas..., eram os estabelecidos pela "economia do Estado e aritmética política", aos quais deveria ser adicionada a capacidade dos governantes de construírem um "claro conhecimento" da realidade, ou seja, adotar uma postura que, "não parando na superfície dos objectos que lhes presentam à vista", buscassem "investigar e compreender a substância das coisas". ${ }^{74}$

Quando o marquês de Pombal endereçava ácida crítica a outros governos europeus, apontados como enfraquecidos por "discórdias e divisões intestinas", "ou com sedições clandestinas e cizânias brotadas pelas venenosas raízes jesuítas", ele afirmava, em contrapartida, que os portugueses seguiam apenas as "resoluçôes e normas" baixadas pelo seu soberano, "constituídos na firmíssima fé de que só ele resolve e determina o que é mais útil aos seus vassalos"..$^{75}$ Certamente, a "firmíssima fé" havia sido avi- 
vada com os processos, julgamentos e execuçōes já referidos, e aos quais poderiam ser ajuntados muitos outros, como o episódio do incêndio da Trafaria, na alvorada do dia 24 de janeiro de 1777, sobre o qual Camilo Castelo Branco comentou:

Este quadro faz de si tamanho horror e tanta afronta à espécie humana, que envergonha o protraí-lo. Um historiador que denomina o Marquês de Pombal - "primeiro estadista português e o iniciador do governo representativo", o Sr. Soriano* termina assim a narrativa dos flagícios da Trafaria: "Foi esta finalmente a última das muitas barbaridades que tão memorável fez a administração do Marquês de Pombal, concluindo assim a carreira despótica do seu governo com a sua tirania, sem que talvez ainda lhe ficasse satisfeito com ela o seu bárbaro coração". Hurra "pelo primeiro estadista português!" Pelo "iniciador do governo representativo", hurra! ${ }^{76}$

Em que pese o descompasso entre os contextos contemplados no comentário de Camilo Castelo Branco, ele oferece uma ideia sobre o julgamento moral e político a que foi submetido o governo de D. José I, um rei que, conforme a crônica, preferia a caça e a música aos negócios de estado e que reinou à "sombra do valido", Sebastião José de Carvalho e Melo. Essa situação, todavia, não se constituiu em "uma singularidade única" para aquele período." Aliás, Ulrich Im Hof faz questão de destacar a situação excepcional de quatro "grandes monarcas" que "quiseram governar de uma forma eficiente e não através de seus ministros": Frederico II, da Prússia; Maria Tereza e José II, da Áustria; e Catarina II, da Rússia. A maior parte dos soberanos, ao contrário desses, vivia "bem longe dos assuntos governativos e dos povos que eram supostos governar, mas sempre apoiados numa tradição inabalável de fidelidade e dedicação. Investidos por Deus no seu cargo régio, só perante Ele eram responsáveis". ${ }^{78}$

Ainda assim, a imagem que se tem de $\mathrm{D}$. José I é a de um rei recluso, vivendo à sombra de seu secretário de estado, o qual foi, como se percebe, responsabilizado pelos excessos que fizeram "tão memorável" aquele governo. ${ }^{79}$ Contudo, apesar da recusa do soberano em participar de atos públicos, ${ }^{80}$ foi ele, depois alcunhado o Reformador, quem recebeu o crédito pelas reformas realizadas durante o seu reinado, enquanto os episódios de "horror" e "inaudita violência", que estiveram presentes em diversos momentos, marcaram, sem dúvida, a "carreira despótica" do governo encabeçado pelo marquês de Pombal.

Despotismo ${ }^{81}$ governo despótico e outras expressões derivadas eram de uso corrente na Europa do século XVIII, como atestam as palavras de António Ribeiro dos Santos, citadas por Kenneth Maxwell. Contudo, na maioria das vezes, seu emprego apontava para formas de governo ditas orientais, que se encontravam "acorrentadas pela superstição, pela educação, pelo hábito e pelo clima. No cristianismo, ao contrário, não pode haver soberania que seja ilimitada, [...] sem outra regra nem razão a não ser a vontade do monarca cristão". Com essas palavras, Louis de Jaucourt apontava alguns dos elementos que definiam um governo despótico: a ausência de leis e o império da vontade de um senhor. De outra parte, considera que, mesmo em um regime monárquico, as ações do soberano deveriam estar constrangidas "pelas regras imutáveis da sabedoria, da justiça e da bondade. [...] Era por isso que Luís XIV reconhecia que nada podia que fosse contrário às leis da natureza, ao direito dos povos e às leis fundamentais do Estado" ${ }^{82}$

Certamente, poderia haver, em território europeu, um mau rei, um mau governante, um mau ministro. Atribuir-lhe, contudo, a pecha de déspota seria indicar que tal indivíduo governava apenas e exclusivamente ao sabor de sua vontade, sem as constrições apontadas por Jaucourt. No caso em questão, parece-me que a maioria dos críticos do Marquês, ao tachá-lo de despótico (ou de tirano), faz menção, exclusivamente, às "atrozes cenas de violência" atribuídas a ele, ${ }^{83}$ como a execução dos Távoras, a repressão ao motim do Porto, a morte do padre Malagrida e o incêndio da Trafaria. Entretanto, alguns somam ao seu "bárbaro coração" a acusação de haver se apropriado dos poderes detidos pelo seu soberano, conduzindo o governo como desejava. Nesse sentido, conforme Joaquim Veríssimo Serrão, o processo dos Távoras marcou o momento em que "a corrente antipombalina viu a sombra de Carvalho e Melo a projectar-se no ânimo do rei"..$^{84}$ 
Não obstante haver indicações que D. José I detinha qualidades necessárias para reinar, ${ }^{85}$ é notório que ele "preferiu a ópera e a caça ao governo". ${ }^{86}$ Contudo, conforme Nuno Monteiro, "há traços conhecidos da personalidade de D. José que permitem afirmar que boa parte das opções políticas que em seu nome se fizeram, se não partiram de sua iniciativa, pelo menos contaram claramente com a sua conivência". ${ }^{87}$ Aliás, ainda que desconfiemos das palavras de António Pereira de Figueiredo, existem muitas evidências de que o rei efetivamente franqueara a Carvalho e Melo "toda a entrada não só do Gabinete, mas também do seu régio coração". 88

A questão da usurpação de poderes do soberano pelo Marquês e o primeiro plano conferido às "atrozes cenas de violência" apenas ocultam uma necessária discussão sobre o conteúdo das reformas empreendidas naquele reinado, as quais, para muitos interessados em estudar esse período da história portuguesa, apenas mostravam "o desejo de cortar, aos ingleses, a influência que tinham sobre o nosso comércio, e aos jesuítas, o domínio que exerciam sobre a consciência pública”, como asseverou, nos anos 1940, o visconde de Carnaxide, que acrescentava: "Afora estes dois anseios, não há outro plano, outro nexo, que una as numerosíssimas modificaçóes introduzidas na vida nacional no tempo de D. José". ${ }^{89}$

Essa opinião, que parece não ter perdido ainda sua validade, é, de certo modo, compartilhada por Nuno Monteiro, para quem a ação legiferante daquele reinado, que pretendeu "modelar o mundo social", não derivou de um "plano prévio desenhado por Carvalho. [...] A coerência na acção pombalina não resulta, assim, de um plano sistemático, mas de uma certa unidade dos métodos de actuação, à qual progressivamente se irá emprestar consciência doutrinária”. ${ }^{90}$ Kenneth Maxwell, apesar de sua declarada intenção de realizar uma "reconstrução intelectual" para "compreender Pombal e o Portugal do século XVIII", também não se preocupou em discutir a existência (ou não) de algum tipo de fundamento, ou "plano prévio" que organizasse as reformas ocorridas no período. Para ele, "Pombal era um adaptador pragmático e sutil”, que soube

[...] servir-se do considerável acervo do pensamento português antigo, como também de suas próprias observaçôes em Londres e Viena. Acima de tudo, não hesitou em agir. Na verdade, a sua ação é a sua obra permanente, para o melhor ou para o pior, dependendo muito de quem se era. ${ }^{91}$

Essas posições parecem expressar o desejo de se encontrar, nos papéis de Carvalho e Melo, algum tipo de programa de reformas anunciado quando de sua nomeação para a Secretaria de Estado do Reino, ou a publicação de algo semelhante. Nada mais excêntrico do que pensar a possibilidade de um anúncio público do que se pretenderia realizar, ainda mais porque a atividade de governo, no contexto português, estava marcada por uma "política de gabinete", não obstante se considerar a presença de uma prática administrativa apoiada na "especialização de um saber estatal", nos moldes do "cameralismo alemão". ${ }^{22}$ Entretanto, desde os anos 1980, vem ganhando terreno uma perspectiva que defende a existência de alguns "princípios" organizando as ações que, durante o reinado de D. José I, visavam realizar o expresso desejo de "civilizar a nação" - torná-la parte da Europa "iluminada" - e de recuperar a glória perdida. Quer dizer, passou-se a considerar que as "paternais, magnânimas e infatigáveis providências" emanadas do Trono poderiam expressar um programa de governo que seguia algum tipo de "teoria" política, ${ }^{93}$ e que estava assentado em um "claro conhecimento" da realidade, como proclamava Carvalho e Melo.

Assim, seguindo sugestão de José Sebastião da Silva Dias, para quem "a prática política” pode ser o resultado de "um projecto político definido", ${ }^{44}$ procurei mostrar, em trabalhos anteriores, ${ }^{95}$ que as "modificações introduzidas" em Portugal, a partir da segunda metade do Setecentos, estavam em consonância com o que se esperava de um governo que promulgava "iluminadas e providentes resoluções e ordens". Além de claras referências às doutrinas do direito natural e do mercantilismo inglês, a observação e a experimentação, tão ao gosto do espírito científico da época, parecem ter oferecido os necessários elementos para a elaboração de um plano que se estendeu a diversas áreas da vida social e econômica, como ficou indicado nas Observaçôes secretíssimas... 
A realidade portuguesa, sem dúvida, limitou o alcance das reformas pretendidas, como expõe o próprio Carvalho e Melo acerca da questão do acolhimento de judeus em territórios portugueses. Desde o século XVII, com Vieira e também com D. Luís da Cunha, circulava a sugestão de se adotar uma política de tolerância em relação aos cristãos-novos e aos judeus. Contudo, em texto não datado, o marquês de Pombal, ao indicar os "meios de se aumentar o pequeno Estado pela sua política, ou governo", reconhecia que "o comércio sempre está nos que professam diferente religião", e que a "liberdade de consciência" não era possível em Portugal, ${ }^{96}$ sem que se alterasse a mentalidade vigente. Aliás, como sugere Ulrich Im Hof, a "época da razão" não se constituiu, na Europa, de forma repentina, sendo necessário que ocorresse uma mudança de ordem ideológica. ${ }^{97}$ Em Portugal, não poderia ser diferente, mesmo considerando que Carvalho e Melo "não hesitou em agir", conforme apontou Kenneth Maxwell.

Não há dúvida sobre a compulsão de Carvalho e Melo em agir. Contudo, não se pode desconhecer sua afeição ao método fundado na observação e na experimentação dos fenômenos, o qual recua, pelo menos, a John Locke e Isaac Newton, que não apenas influenciaram fortemente a "vida política, científica, cultural e religiosa" da Inglaterra, mas também de "boa parte da intelectualidade da Europa Ocidental, na primeira metade do século XVIII, estabelecendo as matrizes gerais do movimento ilustrado neste período". ${ }^{98}$

Entendendo, então, que não é mais possível discutir a "prática política" do reinado de D. José I sem se levar em conta a possibilidade de existência de um conjunto articulado de ideias que a orientasse, ganha expressivo relevo um texto autógrafo de Carvalho e Melo intitulado "Apontados sobre as matérias que devem constituir as regras do mecanismo político". Embora não se possa determinar quando foi redigido, esse texto apresenta um conjunto de considerações sobre como "um pequeno país, com um abreviado número de povo se pode fazer igual em riquezas e em forças a qualquer [outro] muito mais vasto na extensão dos domínios e no número dos habitantes, concorrendo a isso a situação, o comércio e a política". ${ }^{99}$ Dentre as diversas proposiçōes e "regras" expressas no texto, chamam a atenção aquelas referentes aos "meios de se aumentar o pequeno estado pela sua política", na medida em que se pode estabelecer uma notável correspondência delas com alguns dos "efeitos" das "infatigáveis providências" proclamadas nas Observaçôes secretíssimas..., como a necessidade de se "instruir o povo nas artes de conta, peso e medidas", manter os "costumes de vestir e comer com parcimônia", defender a prática comercial por intermédio da legislação e estabelecer maneiras de atrair os estrangeiros "para aumentarem o povo". 100

Ainda mais próximo ao que se poderia identificar como um plano de governo, outro texto autógrafo de Carvalho e Melo demonstra sua familiaridade "com o ser e o agir de um estadista moderno" ${ }^{101}$ Trata-se do "Mecanismo político no qual se oferece à mocidade Portuguesa uma suficiente instrução sobre os interesses de Estado no que pertence ao comércio e à agricultura, cujos princípios se reduzem a termos práticos e mecânicos", no qual são apresentados os elementos "necessários" para atender aos "inteiros interesses do Estado". ${ }^{102}$ Assim, seguindo princípios estabelecidos pela "economia do Estado e aritmética política", ${ }^{103}$ o secretário de estado de D. José I recomendava, entre tantas outras providências, o exame "do número dos habitantes do país de que se quer tratar", "do valor dos fundos de terras", "do que produzem as finanças", "de quanto somam anualmente as fazendas que pelo comércio se exportam", "dos gêneros e mercadorias recebidos dos estrangeiros", "do que ganha o povo pelo trabalho, conferido com o que dispende pelo luxo, para saber quanto lhe fica poupando", "do que importa o geral comércio da Europa" e "de quantas toneladas somam todos os navios da Europa".

Como se pode perceber, são preocupações que oscilam entre o local e o contexto europeu, requisitando uma notável capacidade de observação e diagnóstico para a adoção de medidas que correspondessem aos "interesses do Estado", os quais podem ser resumidos à fórmula "civilizar a nação" e recuperar a força econômica e política de Portugal frente às outras nações europeias. Nesse entendimento, compreende-se que as reformas empreendidas no reinado de D. José I podem e devem ser consideradas inseridas em um plano articulado, que foi sendo posto em prática à medida que as condições do contexto social e político o permitiam. ${ }^{104} \mathrm{Ou}$ seja, "a coerência" da ação pombalina resulta, sim, "de um plano sistemático", o qual, mesmo que não tenha sido redigido antes do ingresso de Carvalho e Melo na Secre- 
taria de Estado do Reino, já fazia parte de suas preocupaçôes desde a época em que esteve em Londres, quando tomou contato com as ideias daqueles "que deram em Inglaterra o método seguro, com que hoje se consideram nestes reinos, pelos ministros políticos, os interesses da navegação e comércio, pelo que lhes pertence". ${ }^{105}$ De fato, como destaca Teresa Fonseca, entre 1738 e 1749, o então funcionário da Secretaria de Estado dos Negócios Estrangeiros teve condições para formar

[...] uma vasta biblioteca da qual constavam, a par de numerosos livros de cultura geral, muitos dedicados à aprendizagem da ciência política, [...] das doutrinas do direito natural e das gentes, [...] e ainda várias obras de teor econômico, incluindo finanças, assuntos coloniais, alfândegas, artes, manufaturas e agricultura. ${ }^{106}$

Enfim, parece-me que Carvalho e Melo realmente colocou em prática a exigência de os governantes construírem um "claro conhecimento" dos estados por eles administrados, em consonância com o ideal científico da época. Assim, ele realizou uma acurada observação de diversos elementos da sociedade portuguesa - comércio, instituições, educação, agricultura etc. - para levar ao seu soberano as medidas que julgava necessárias para fazer com que "um pequeno país" se igualasse a outros "em riqueza e em forças". Essas medidas, por sua vez, derivavam de uma "teoria" (mais econômica que política) e formavam um conjunto de "regras" por ele adrede idealizado e exposto no que designou de "mecanismo político".

\section{Notas}

${ }^{1}$ SOARES, Luiz Carlos. A Albion revisitada no século XVIII: novas perspectivas para os estudos sobre a ilustração inglesa. Tempo, n. 16, p. 175-206, 2004, p. 193.

${ }^{2}$ VENTURI, Franco. Utopia e reforma no Iluminismo. Bauru: Edusc, 2003 [1970], p. 51. Ver especialmente o capítulo 5, "Cronologia e geografia do Iluminismo".

${ }^{3}$ BAUMER, Franklin L. O pensamento europeu moderno, volume 1 (séculos XVII e XVIII). Lisboa: Ediçôes 70, 1990 [1977], p. 166.

${ }^{4}$ Este texto decorre de pesquisa financiada pela Coordenação de Aperfeiçoamento de Pessoal de Nível Superior (CAPES), Ministério da Educação, Brasil.

${ }^{5}$ Mesmo não concordando, no todo, com o "julgamento" que Kenneth Maxwell faz da "história da administração pombalina", ela apresenta, sem dúvida, "um antídoto importante para a visão excessivamente linear e progressiva do papel do Iluminismo no século XVIII na Europa e da relação entre o Iluminismo e o exercício do poder do Estado". MAXWELL, Kenneth. Marquês de Pombal: paradoxo do Iluminismo. Rio de Janeiro: Paz e Terra, 1996, p. 172.

${ }^{6}$ Entendo que, ao final, a referência a uma "época pombalina" será mais abrangente que no sentido proposto por Francisco Falcon, para quem ela "representa apenas uma espécie de expediente para justificar um certo recorte cronológico". FALCON, Francisco Calazans. Pombal e o Brasil. In: TENGARRINHA, José (Org.). História de Portugal. Bauru: Edusc, 2000, p. 149-161, p. 149.

${ }^{7}$ DIAS, José Sebastiāo da Silva. Pombalismo e projecto politico. Lisboa: Centro de História da Cultura da Universidade Nova de Lisboa, 1984, p. 113-118.

${ }^{8}$ SERRÃO, Joaquim Veríssimo. O marquês de Pombal: o homem, o diplomata e o estadista. 2.ed. Lisboa: s/ed., 1987, p. 160.

${ }^{9}$ GRAMOZA, José Pedro Ferraz. Successos de Portugal: memórias históricas, políticas e civis, em que se descrevem os mais importantes successos occorridos em Portugal desde 1742 ate o anno de 1804. Lisboa: Typographia do Diário da Manhã, 1882, p. 245. Nas citações de textos de época, optei pela modernização da linguagem, visto trabalhar com fontes publicadas em diferentes momentos. Contudo, procurei manter a grafia dos títulos.

${ }^{10}$ RATTON, Jacome. Recordaçôes de Jacome Ratton sobre ocorrências do seu tempo, de maio de 1747 a setembro de 1810. 2.ed. Coimbra: Editora da Universidade, 1920, p. 231.

${ }^{11}$ GRAMOZA, op. cit., p. 246.

* Por "cocar", entende-se um enfeite de penas sobre o chapéu.

${ }^{12}$ BARBOSA, Domingos Caldas. Narração dos Applausos com que o Juiz do Povo e a Casa dos Vinte-Quatro festeja a felicissima inauguração da Estatua Equestre, onde tambem se expōem as allegorias dos carros, figuras e tudo mais concernente as ditas Festas. Lisboa: Regia Officina Typografica, 1775, p. 3.

${ }^{13}$ Ver MONTEIRO, Nuno Gonçalo. D. José: na sombra de Pombal. Lisboa, Círculo de Leitores, 2006, p. 256-257. A informação sobre a participação "incógnita" da família real na cerimônia tem como fonte o embaixador espanhol. Nuno Monteiro também destaca que "são curiosamente muito parcas as alusōes à cerimônia feitas pela rainha Mariana Vitória na carta que então escreveu ao irmão" (Ibidem, p. 257). 
${ }^{14}$ BRANCO, Camilo Castelo. O perfil do marquês de Pombal. Lisboa: Folhas e Letras, 2003 [1882], p. 188-189.

${ }^{15} \mathrm{O}$ príncipe D. José, afinal, contraiu núpcias com sua tia D. Maria Francisca Benedita, em 21 de fevereiro de 1777, três dias antes da morte de seu avô. Em 11 de setembro de 1788, o príncipe D. José faleceu em Lisboa.

${ }^{16}$ Ver FRANÇA, José-Augusto. Une ville des Lumières: la Lisbonne de Pombal. Paris: Imprensa Nacional, 1965, além de diversos outros textos que esse autor dedicou ao assunto.

${ }^{17}$ FRANÇA, José-Augusto. A reconstrução de Lisboa e a arquitetura pombalina. 3.ed. Lisboa: ICLP, 1989, p. 79.

${ }^{18}$ TAVARES, Rui. O pequeno livro do grande terramoto. 2aㅡ ed. Lisboa: Tinta-da-China, 2005, p. 80-81.

${ }^{19}$ FRANÇA, José-Augusto. Lisboa: urbanismo e arquitectura. 2.ed. Lisboa: ICLP, 1989, p. 41-42.

${ }^{20}$ CASTRO, João Bautista de. Mappa de Portugal antigo, e moderno. Tomo Terceiro, Parte V. Lisboa: Officina Patriarcal de Francisco Luiz Ameno, 1763, p. 89.

${ }^{21}$ MAXWELL, op. cit., p. 24.

${ }^{22}$ FRANÇA, A reconstrução de Lisboa..., op. cit., p. 12. Importante notar que o comentário de Kenneth Maxwell é posterior ao de José-Augusto França; mesmo assim, este último parece oferecer uma cifra mais exata que o primeiro.

${ }^{23}$ Ver LISBOA, Amador Patrício de. Memorias das principaes providencias que se derão no terremoto que padeceo a Corte de Lisboa no anno de 1755. Lisboa, 1758.

${ }^{24}$ Alvará de 12 de maio de 1758, que estabelece os direitos públicos e particulares da reedificação da cidade de Lisboa. Apud FRANÇA, José-Augusto. Lisboa pombalina e o Iluminismo. 2.ed. rev. aum. Lisboa: Bertrand, 1977, p. 309-313.

${ }^{25}$ RATTON, op. cit.,, p. 220-224.

${ }^{26}$ GRAMOZA, op. cit., p. 245.

${ }^{27}$ FRANÇA, Lisboa, op. cit., p. 46. Conforme o mesmo autor, “Toute ouvre accomplie a son couronnement. Celui de la reconstruction de Lisbonne a été la statue équestre du roi Joseph I ${ }^{\mathrm{er}}$, placée à l'éntree naturelle de Lisbonne, au milieu du 'Terreiro do Paço' qui venait de recevoir um nouveau nom, autrement significatif: Place du Commerce." FRANÇA, Une ville..., op. cit., p. 163.

${ }^{28}$ MAXWELL, op. cit., p. 27.

${ }^{29}$ FRANCO, José Eduardo. Quem influenciou o Marquês de Pombal? Ideólogos, ideias, mitos e a utopia da Europa do Progresso. Atas do $3^{\circ}$ Colóquio Relaçôes Luso-Brasileiras: entre Iluminados e Românticos. Polo de Pesquisa sobre Relações LusoBrasileiras, Real Gabinete Português de Leitura. Rio de Janeiro, 2006.

${ }^{30}$ Segundo António Pereira de Figueiredo, a cidade de Lisboa obrigou-se a "levantar no Terreiro do Paço ao seu Magnânimo Restaurador, El Rei D. José I, uma estátua equestre colossal”, em agradecimento às "tão grandes e tão interessantes obras" de sua reconstrução. FIGUEIREDO, António Pereira de. Elogios dos reis de Portugal em latim, e em portuguez illustrados de notas historicas e criticas. Lisboa: Officina de Simão Thaddeo Ferreira, 1785, p. 265.

${ }^{31}$ CASTRO, Joaquim Machado de. Descripção analytica da execução da estatua equestre, erigida em Lisboa á gloria do Senhor Rei Fidelissimo D. José I. Lisboa: Imprensa Régia, 1810, p. 53-54.

${ }^{32}$ Ibidem, s/p.

33 “[...] no rosto, quis fazer um retrato parecido quanto eu pudesse; e tendo Sua Majestade benignidade para conceder-me a honra de que na sua presença eu desse alguns toques de semelhança na sua imagem (pois que em outras ocasiões me havia já conferido a graça de admitir-me a modelar na sua Real presença) não se me consentiu intentar isso, e o único recurso que tive foi valer-me do meio perfil expressado na moeda e da estampa de Carpinetti, com alguma vista casual. [...] Apesar destes inconvenientes, muitas pessoas o acham bastante parecido". Ibidem, p. 69-70.

${ }^{34}$ MENDES, António Rosa. Ribeiro Sanches e o marquês de Pombal: intelectuais e poder no absolutismo esclarecido. Cascais: Patrimônia, 1998, p. 249. Em 12 de novembro de 1774, Ribeiro Sanches registra em seu diário que, desde o ano de 1759, era favorecido com uma "tença de 360 mil rs." por ano. Idibem, p. 248.

${ }^{35}$ Apud TEIXEIRA, Ivan. Mecenato pombalino e poesia neoclássica. São Paulo: Edusp, 1999, p. 110.

${ }^{36}$ Apud BARBOSA, op. cit., p. 55.

${ }^{37}$ FIGUEIREDO, António Pereira de. Parallelo de Augusto Cesar e de Dom José o magnanimo Rei de Portugal. Lisboa: Regia Officina Typografica, 1775, fls. 31-33 e 34.

${ }^{38} \mathrm{O}$ medalhão com a efígie do marquês de Pombal, colocado na parte frontal do pedestal da estátua, foi retirado por ordem de D. Maria I. Basílio de Magalhães, fiel ao Marquês, escreveu um soneto em que acusava o povo de "injusto", pois este havia esquecido os "grandes serviços" prestados por Pombal, a quem declarava que "para ser imortal, teu nome augusto não depende do bronze derretido". Apud TEIXEIRA, op. cit., p. 118.

${ }^{39}$ Ver SANTOS, Antonio Cesar de Almeida. Para viverem juntos em povoaçôes bem estabelecidas: um estudo da política urbanistica pombalina. Tese de Doutorado apresentada ao Programa de Pós-graduação em História da UFPR. Curitiba, 1999, p. 14-33. 
${ }^{40}$ Existem diversas versōes publicadas desse texto; todas com pequenas variações. Neste artigo, optei por trabalhar com a versão publicada em MELO, op. cit. Conforme indicação do editor do livro, entende-se que o referido texto foi transcrito de Memorias secretissimas do Marquez de Pombal, apresentadas ao senhor rei D. José, dois anos antes da sua morte. Lisboa: Officina da Viúva de Lino da Silva Godinho, 1821. Para dirimir dúvidas, também considerei a versão publicada no Gabinete Histórico, tomo XVII, Lisboa, p. 305-332, 1831 (sob o título de Observaçôes secretíssimas do Marquês de Pombal sobre a collocação da Estatua Equestre de Sua Majestade o senhor D. José I).

${ }^{41}$ Observações secretíssimas..., op. cit., p. 249 e 251.

${ }^{42}$ Por decreto de 3 de setembro de 1759, a Companhia de Jesus foi expulsa do Reino e dos domínios de Portugal. Após uma intensa campanha antijesuítica, a ordem foi extinta em 1773, por meio de bula papal. Além de terem sido implicados no atentado sofrido pelo rei, em 1758, Kenneth Maxwell entende que "foi a reação dos jesuítas aos tratados de Madri que tornou problemáticas as possibilidades de uma solução pacífica entre a Sociedade e o Estado pombalino". MAXWELL, op. cit., p. 73.

${ }^{43}$ MONTEIRO, op. cit., p. 168. No capítulo intitulado "O tempo das providências", Nuno Monteiro trata dos "progressos resultantes das paternais, magnânimas e infatigáveis providências de Sua Majestade”, destacando aspectos referentes ao comércio, às finanças, às "artes fabris" e ao alcance das "providências" nos domínios ultramarinos, particularmente, no Brasil (Ibidem, p. 166-184). Grifos meus.

${ }^{44}$ Observaçôes secretíssimas..., op. cit., p. 245-249.

45 Ibidem, p. 249-250.

${ }^{46}$ LOPES, Maria Antónia. Mulheres, espaço e sociabilidade: a transformação dos papéis femininos em Portugal à luz de fontes literárias (segunda metade do século XVIII). Lisboa: Livros Horizonte, 1989, p. 46.

${ }^{47}$ CHAVES, Castelo-Branco. Prefácio. In: O Portugal de D. João V visto por três forasteiros. 2.ed. Lisboa: Biblioteca Nacional, 1989, p. 22.

${ }^{48}$ Apud O Portugal de D. João V..., p. 269.

${ }^{49}$ Não obstante a destruição provocada, o terremoto de 1o de novembro de 1755, passou a ser visto, em Portugal, como o inaugurador de novos tempos. Como aponta Maria Antónia Lopes, na segunda metade do século XVIII, "o terramoto constituía para os coevos um marco temporal que delimitava, nas suas representações mentais, dois mundos opostos: o da bisonheria e o da desenvoltura." LOPES, op. cit., p. 69.

${ }^{50}$ GORANI, Giuseppe. Portugal: a Corte e o país nos anos de 1765 a 1767. Lisboa: Lisóptima Edições, 1989, p. $100-101$.

${ }^{51}$ GORANI, op. cit., p. 12 e 273.

52 Observaçôes secretissimas..., op. cit., p. 251. Grifo meu.

53 SERRÃO, op. cit., p. 86.

${ }^{54}$ Sentença da alçada que ElRey, Nosso Senhor, mandou conhecer da rebelião sucedida na cidade do Porto em 1757; citada em SERRÃO, op. cit., p. 134. Não obstante tantos exemplos, no início de 1777, ainda foi necessária a intervenção do Intendente Geral de Polícia Diogo Inácio de Pina Manique, no episódio do incêndio da Trafaria (ver adiante).

${ }^{55}$ MAXWELL, op. cit., p. 42 e 43.

${ }^{56}$ Observaçôes secretíssimas..., op. cit., p. 245. Embora não ocorra uma alteração no sentido, o texto desse trecho encontra-se modificado em relação ao publicado no Gabinete Histórico: "e quando antes, tudo o que eles costumão fabricar entrava pela barra de reinos estrangeiros, se viu agora que as manufaturas nacionais forneceram... porque até os espelhos e placas e vidros de beber foram feitos nas fábricas dos vassalos de Sua Majestade" (op. cit., p. 307-308).

${ }^{57}$ CASTRO, Armando de. A política económica do marquês de Pombal e a sociedade portuguesa do século XVIII. Revista de História das Ideias (O marquês de Pombal e o seu tempo), v. IV, Tomo I, p. 41-49, 1982-1983, p. 44-45.

${ }^{58}$ MONTEIRO, op. cit., p. 176-178.

${ }^{59}$ CASTRO, op. cit., p. 45.

${ }^{60}$ CARVALHO, Rômulo de. O recurso a pessoal estrangeiro no tempo de Pombal. Revista de História das Ideias (O marquês de Pombal e o seu tempo), Coimbra, v. IV, Tomo I, p. 91-115, 1982-1983, p. 99-101. A marcada presença de estrangeiros em solo português também contribuiu para mudanças nas sociabilidades, na medida em que eles trouxeram novas "modas", como destaca Maria Antónia Lopes, citando o viajante Carl Ruders que, em Observaçôes sobre Portugal (1803), escreveu: “o grande afluxo de estrangeiros, especialmente de famílias inglesas, tem introduzido no país, nos últimos 20 ou 30 anos, muitos dos seus costumes, tem revelado aos portugueses os atractivos da vida em sociedade”. LOPES, op. cit., p. 70.

${ }^{61}$ MONTEIRO, op. cit., p. 172.

${ }^{62}$ Pode-se pensar que a questão da agricultura, em Portugal, veio a ser contemplada de modo mais sistemático após a criação da Academia Real das Ciências de Lisboa (1779), como demonstram as muitas Memórias publicadas por essa instituição.

${ }^{63}$ SERRÃO, José Vicente. O quadro econômico. In: História de Portugal, v. 4 (O Antigo Regime, 1620-1807). Lisboa: Editorial Estampa, 1998, p. 67-109, p. 76-77. José Vicente Serrão complementa: "A concorrência tornara-se, assim, o elemento 
pivot de um círculo vicioso, no qual o sector cerealífero estava enredado e bloqueado: a sua própria existência (inevitável) desestimulava a produção nacional; mas quanto mais esta se retraía do mercado, mais era necessário aumentar as importaçōes, agravando-se, por conseguinte, o peso da concorrência desfavorável” (Ibidem, p. 77).

${ }^{64}$ Carta de lei de 4 de fevereiro de 1773. In: MELO, op. cit., p. 135-137. Esta lei, de fato, pretende regular a comercialização de bens, na medida em que se foram "acumulando estorvos, para que os sobreditos frutos não pudessem girar entre os meus vassalos".

${ }^{65}$ Ver SERRÃO, op. cit., p. 140.

${ }^{66}$ FIGUEIREDO, Elogios dos reis de Portugal..., op. cit., p. 263.

${ }^{67}$ Ver $A$ administração de Sebastião Joze de Carvalho e Mello, Conde de Oeiras, Marquez de Pombal, secretario de estado, e primeiro ministro de sua magestade fidelissima o Senhor D. Joze I, rei de Portugal, traduzida do francez, por Luis Innocencio de Pontes Athaide e Azevedo. Lisboa: Typ. Lusitana, 1841. Tomo I, p. 208.

${ }^{68}$ CASTRO, op. cit., p. 47-48.

${ }^{69}$ Observaçôes secretíssimas..., op. cit., p. 245.

70 "No ano de 1777, consumido de uma dilatada e penosa enfermidade, passou El-Rei a melhor vida no dia 24 de fevereiro, em idade de sessenta e três anos, dos quais reinou vinte e sete. E ao terceiro dia da sua morte, foi sepultado em São Vicente". FIGUEIREDO, Elogios dos reis de Portugal..., op. cit., p. 267.

${ }^{71}$ MONTEIRO, op. cit., p. 166.

${ }^{72}$ Observaçôes secretíssimas..., op. cit., p. 249.

${ }^{73}$ Ibidem, p. 251-252. Grifos meus.

${ }^{74}$ Ibidem, p. 245.

${ }^{75}$ Ibidem, p. 251.

${ }^{76}$ BRANCO, op. cit., p. 186. Grifo meu.

* Menção a Simão José da Luz Soriano, autor do texto História do reinado de El-Rei D. José e da administração do marquês de Pombal, publicado em 1867. Segundo Carnaxide, a obra de Soriano é "repositório de fatos contados sem nenhum espírito crítico ou filosófico. Considera o ministro precursor consciente do demoliberalismo, motivo por que o elogia. O estilo tem a doçura duma boa idade". A esse comentário, pode-se contrapor o endereçado à obra de Camilo Castelo Branco, publicada em 1882: "Constituem-no quinze ensaios de crítica histórica, torrenciais de talento e de verrina contra o perfilado". Ver CARNAXIDE, Visconde de [Antonio de Souza Pedroso Carnaxide]. O Brasil na administração pombalina (economia e política externa). 2.ed. São Paulo: Ed. Nacional, 1979 [1940], p. 297 e 283.

77 MONTEIRO, op. cit., p. 211.

${ }^{78}$ HOF, Ulrich Im. A Europa no século das Luzes. Lisboa: Editorial Presença, 1995, p. 21 e 23.

${ }^{79}$ Em relação ao episódio da Trafaria, como D. José I já se encontrava bastante doente na ocasião, e ainda mais ausente dos negócios de governo, parece razoável presumir que a ordem dada ao Intendente Geral de Polícia, Pina Manique, para aniquilar o povoado instalado à margem esquerda do rio Tejo, tido como um esconderijo de pessoas que fugiam ao recrutamento militar, partiu do marquês de Pombal.

${ }^{80}$ Nuno Monteiro, ao considerar D. José I “um homem de seu tempo", alude à demonstração de uma "sensibilidade pósbarroca”, caracterizada pela relutância dos soberanos em se exibirem em público, preferindo uma vida mais retirada. Nesse sentido, cita as memórias de "um militar francês", Charles François Dumoriez: "o rei não tem nenhuns momentos de representação, não se avistando com os ministros estrangeiros senão nos dias de beija-mão; passa o resto do tempo com a sua família, ou na caça que ama com paixão”. MONTEIRO, op. cit., p. 225-226.

81 "Despotismo, s. m. Autoridade, poder absoluto. Abuso de poder contra a razão, contra a Lei; excesso do direito, que faz o que governa”. SILVA, Antonio de Moraes. Diccionario de lingua portuguesa. Rio de Janeiro: Officinas da S. A. Litho-Typographia Fluminense, 1922, v. 1, p. 598. Bluteau traz o termo "despótico", o qual deriva da palavra grega "Despotis, que quer dizer Senhor", de onde o significado "Império absoluto, ou de Senhor absoluto". BLUTEAU, Raphael. Vocabulario portuguez \& latino. Coimbra: Collegio das Artes da Companhia de Jesu, 1712-1728, 8v., v. 3, p. 170.

${ }^{82}$ JAUCOURT, Louis de. Despotismo. In: DIDEROT, Denis. Verbetes políticos da Enciclopédia. São Paulo: Discurso Editorial; Editora da Unesp, 2006, p. 74 e 75.

${ }^{83}$ Para Ulrich Im Hof, o "zelo reformista” do marquês de Pombal é apenas uma de suas faces; "a outra é caracterizada pela arbitrariedade e pela crueza. [...] Antecipando-se aos demais, Pombal tinha demonstrado ao mundo que o Iluminismo vindo de cima podia ter dois rostos: por um lado, progresso, construção, modernização; mas, por outro, tirania absolutista e impiedosa, de onde não está ausente a brutalidade”. HOF, op. cit., p. 237-238.

${ }^{84}$ SERRÃO, op. cit., p. 86.

${ }^{85}$ Em 1743, a princesa D. Mariana Vitória informava sua mãe, Isabel Farnésio, que "o meu príncipe [...] sabe discorrer sobre todas as matérias com uma grande justeza” (Apud MONTEIRO, op. cit., p. 41). O marquês de Pombal, já afastado da 
Corte, redigiu um texto no qual comentava sobre o preparo intelectual de D. José I, descrito como um arguto observador da política portuguesa e um profundo conhecedor da História, da Geografia e dos princípios da Geometria e da Aritmética Política (Ver BIBLIOTECA NACIONAL DE PORTUGAL (BNP). Códice 13286. Texto referente à ação movida contra o marquês de Pombal por Francisco Galhardo de Mendanha, inserido no 4o volume da coleção intitulada Obras do Ilmo. $e$ Exmo. Sebastiāo José de Carvalho e Mello).

${ }^{86}$ MAXWELL, op. cit., p. 4.

${ }^{87}$ MONTEIRO, op. cit., p. 228.

${ }^{88}$ FIGUEIREDO, Parallelo..., op. cit., fls. $31-33$ e 34.

${ }^{89}$ CARNAXIDE, op. cit., p. 1-2. Grifo meu.

${ }^{90}$ MONTEIRO, op. cit., p. 101.

${ }^{91}$ MAXWELL, op. cit., p. 169-170.

${ }^{92}$ Ver SENELLART, Michel. As artes de governar: do "regimen" medieval ao conceito de governo. São Paulo: Editora 34, 2006, p. 286. Michel Senellart apresenta uma interessante distinção entre dois modelos de governo presentes no absolutismo monárquico do século XVII (mas se pode estender essa situação para o século XVIII): de um lado, aponta a existência de uma "política de gabinete", apoiada na noção de "segredo" e caracterizada como "modelo francês"; de outro lado, apresenta o "cameralismo alemão", cuja atividade governativa está orientada pela "especialização de um saber estatal”. Para José Damião Rodrigues, o "reformismo activo" atribuído ao marquês de Pombal foi "de inspiração cameralista”, tratando-se de uma prática de governo que tentou "romper com um modelo administrativo 'passivo' e com o equilíbrio de poderes tradicional, procurando impor uma diferença enquanto estratégia política”. RODRIGUES, José Damião. "Para o socego e tranquilidade publica das ilhas": fundamentos, ambição e limites das reformas pombalinas nos Açores. Conferências e comunicaçôes da VIa Jornada Setecentista. Curitiba: Aos Quatro Ventos; CEDOPE, 2006, p. 35-56, p. 38.

${ }^{93}$ Conforme Michel Senellart, a "teoria” política seria a responsável pela formulação de leis gerais; a "prática” política, por sua vez, estaria relacionada ao conceito de "razão de estado", na medida em que cada estado irá propor e adotar as medidas necessárias para a sua conservação. SENELLART, op. cit., p. 39.

94 "A prática política não é um produto mecânico da teoria política. Supõem-na, com formulação explícita ou em estado meramente implícito; reflecte-a, com mais ou menos entorses, com mais ou menos desvios; mas obriga-a também a correcçôes centrais ou periféricas e ajusta-a ao particular das conjunturas ou dos momentos. É por isso que estudar a teoria política de uma corrente, de um governo ou de uma época não equivale a conhecer a respectiva prática política, e vice-versa. [...] A prática política pode ser apenas a resultante assistémica de soluções não programadas para problemas conjunturais imprevistos. Mas pode ser também, no todo ou em parte, a sequela, bem ou mal ajustada, de um projecto político definido". DIAS, op. cit., p. 1 e 2.

${ }^{95}$ Ver SANTOS, Antonio Cesar de Almeida. Alguns princípios da política e da administração do reinado de D. José I (17501777). Textos da 26a Reunião da SBPH. Porto Alegre: SBPH, 2006, p. 1-15; SANTOS, Antonio Cesar de Almeida. Observações sobre a teoria e a prática política pombalina: em busca da harmonia e consonância da sociedade civil. Anais da XXIV Reuniāo da SBPH. Curitiba: SBPH, 2005, p. 129-136.

96 “ $4^{\mathrm{a}}$ [regra quanto aos meios de se aumentar o pequeno Estado pela sua política, ou governo. Vantagens aos povos.] A liberdade de consciência que não é entre nós praticável, Petty - Cap. $1^{\circ}, \$ 40$ até 52 , excelentes razões porque o comércio sempre está nos que professam diferente religião”. BNP. COLEÇÃO POMBALINA (PBA). Códice 686, fls. 187-190, manuscrito autógrafo, sem data. MELO, Sebastião José de Carvalho e. "Apontados sobre as matérias que devem constituir as regras do Mecanismo Político”, fl. 190.

${ }_{97}$ "A partir dos finais do século XVII, adoptando um ritmo mais ou menos rápido consoante os países, o primeiro período do Iluminismo libertou-se corajosamente das premissas do pensamento barroco, postulando uma visão mais livre e lançando as primeiras pedras para construir uma época da razão. É evidente que tal alteração de mentalidades tinha de ocorrer num quadro tradicional de referências. [... Foi nos bancos da escola que ela se familiarizou com o novo espírito e aprendeu que se podiam dissipar antigos preconceitos sem destruir arbitrariamente os valores tradicionais. Cautelosamente, os governos deram início ao seu programa de reformas". HOF, op. cit., p. 230. Grifo meu.

${ }^{98}$ SOARES, op. cit., p. 179.

${ }^{99} \mathrm{BNP} / \mathrm{PBA}$. Códice 686, fls. 187-187v.

${ }^{100}$ Ver, nesse aspecto, as considerações de Rômulo de Carvalho e Maria Antónia Lopes; cf. supra, nota 61.

${ }^{101}$ DIAS, op. cit., p. 113-118.

${ }^{102}$ BNP/PBA. Códice 686, fls. 191-199, manuscrito autógrafo, sem data. MELO, Sebastião José de Carvalho e. "Mecanismo político no qual se oferece à mocidade Portuguesa uma suficiente instrução sobre os interesses de Estado no que pertence ao comércio e à agricultura, cujos princípios se reduzem a termos práticos e mecânicos”. Ambos os textos autógrafos aqui indicados conformam-se a um sumário de obra a ser posteriormente redigida, mas que não chegou a ser realizada. 
${ }^{103}$ Sobre a adoção dos princípios da Aritmética Política no reinado de D. José I, ver SANTOS, Antonio Cesar de Almeida. Aritmética política e a administração do estado português na segunda metade do século XVIII. In: DORÉ, Andréa; SANTOS, Antonio Cesar de Almeida Santos (Orgs.). Temas setecentistas: governos e populaçôes no Império português. Curitiba: UFPR; Fundação Araucária, 2009, p. 143-152.

${ }^{104}$ Não se pode esquecer, por exemplo, que a Guerra dos Sete Anos (1756-1763) foi um evento que obrigou o dispêndio de recursos financeiros e que requereu a atenção do governo português, interferindo no curso das pretendidas reformas.

${ }^{105}$ BNP/PBA. Códice 657. Carta de Sebastião José de Carvalho e Melo a Marco António de Azevedo Coutinho, secretário de estado dos negócios estrangeiros e da guerra, de 19 de fevereiro de 1742. "Foram, primeiro Cromwell e depois Guilherme Patti [sic], que viveu no tempo de el-rei Carlos $2^{\circ}$, aqueles que deram em Inglaterra o método seguro, com que hoje se consideram nestes reinos, pelos ministros políticos, os interesses da navegação e comércio, pelo que lhes pertence”.

${ }^{106}$ FONSECA, Teresa. Absolutismo e municipalismo, Évora 1750-1820. Lisboa: Colibri, 2002, p. 567.

\section{Fontes e referências bibliográficas}

A administração de Sebastiāo Joze de Carvalho e Mello, Conde de Oeiras, Marquez de Pombal, secretario de estado, e primeiro ministro de sua magestade fidelissima o Senhor D. Joze I, rei de Portugal, traduzida do francez, por Luis Innocencio de Pontes Athaide e Azevedo. Lisboa: Typ. Lusitana, 1841. Tomo I.

AZEVEDO, João Lúcio. O marquês de Pombal e sua época. São Paulo: Alameda, 2004 [1909].

BARBOSA, Domingos Caldas. Narração dos Applausos com que o Juiz do Povo e a Casa dos Vinte-Quatro festeja a felicissima inauguração da Estatua Equestre, onde tambem se expõem as allegorias dos carros, figuras e tudo mais concernente as ditas Festas. Lisboa: Regia Officina Typografica, 1775. Edição digital da Biblioteca Nacional de Portugal, disponível em <http://purl.pt/14323>

BAUMER, Franklin L. O pensamento europeu moderno, volume 1 (séculos XVII e XVIII). Lisboa: Edições 70, 1990 [1977].

BLUTEAU, Raphael. Vocabulario portuguez \& latino. Coimbra: Collegio das Artes da Companhia de Jesus, 1712-1728, 8 v. Edição digital do Instituto de Estudos Brasileiros da USP, disponível em <http://www.ieb.usp. $\mathrm{br} /$ online/dicionarios/Bluteau>

BRANCO, Camilo Castelo. O perfil do marquês de Pombal. Lisboa: Folhas e Letras, 2003 [1882].

CARNAXIDE, Visconde de [Antonio de Souza Pedroso Carnaxide]. O Brasil na administração pombalina (economia e política externa). 2a ed. São Paulo: Ed. Nacional, 1979 [1940].

CARVALHO, Rômulo de. O recurso a pessoal estrangeiro no tempo de Pombal. Revista de História das Ideias (O marquês de Pombal e o seu tempo), Coimbra, v. IV, Tomo I, p. 91-115, 1982-1983.

CASTRO, Armando de. A política económica do marquês de Pombal e a sociedade portuguesa do século XVIII. Revista de História das Ideias (O marquês de Pombal e o seu tempo), Coimbra, v. IV, Tomo I, p. 41-49, 1982-1983.

CASTRO, João Bautista de. Mappa de Portugal antigo, e moderno. Tomo Terceiro, Parte V. Lisboa: Officina Patriarcal de Francisco Luiz Ameno, 1763.

CASTRO, Joaquim Machado de. Descripção analytica da execução da estatua equestre, erigida em Lisboa á gloria do Senhor Rei Fidelissimo D. José I. Lisboa: Imprensa Régia, 1810. Edição digital da Biblioteca Nacional de Portugal, disponível em <http://purl.pt/960>

DIAS, José Sebastião da Silva. Pombalismo e projecto politico. Lisboa: Centro de História da Cultura da Universidade Nova de Lisboa, 1984.

DIDEROT, Denis. Verbetes políticos da Enciclopédia. São Paulo: Discurso Editorial; Editora da Unesp, 2006.

FALCON, Francisco Calazans. Pombal e o Brasil. In: TENGARRINHA, José (Org.). História de Portugal. Bauru, Edusc, 2000, p. 149-161.

FIGUEIREDO, António Pereira de. Elogios dos reis de Portugal, em latim e em portuguez, illustrados de notas historicas, e criticas. Lisboa: Officina de Simão Thadeo Ferreira, 1785. Edição digital da Biblioteca Nacional de Portugal. Disponível em <http://purl.pt/13844>

FIGUEIREDO, António Pereira de. Parallelo de Augusto Cesar e de Dom José o magnanimo Rei de Portugal. Lisboa: Regia Officina Typografica, 1775.

FONSECA, Teresa. Absolutismo e municipalismo, Évora 1750-1820. Lisboa: Colibri, 2002. 
FRANÇA, José-Augusto. A reconstrução de Lisboa e a arquitetura pombalina. $3^{\underline{a}}$ ed. Lisboa: ICLP, 1989. . Lisboa: urbanismo e arquitectura. 2a ed. Lisboa: ICLP, 1989. Lisboa pombalina e o Iluminismo. $2^{\underline{a}} \mathrm{ed}$. rev. aum. Lisboa: Bertrand, 1977. Une ville des Lumières: la Lisbonne de Pombal. Paris: Imprensa Nacional, 1965.

FRANCO, José Eduardo. Quem influenciou o Marquês de Pombal? Ideólogos, ideias, mitos e a utopia da Europa do Progresso. Atas do $3^{\circ}$ Colóquio Relaçôes Luso-Brasileiras: entre Iluminados e Românticos. Polo de Pesquisa sobre Relações Luso-Brasileiras, Real Gabinete Português de Leitura. Rio de Janeiro, 2006. Disponível em <http:// www.realgabinete.com.br/coloquio/3_coloquio_outubro/paginas/12.htm\#_ftn1> Acesso em 13/10/2007.

GORANI, Giuseppe. Portugal: a Corte e o país nos anos de 1765 a 1767. Lisboa: Lisóptima Edições, 1989.

GRAMOZA, José Pedro Ferraz. Successos de Portugal: memórias históricas, politicas e civis, em que se descrevem os mais importantes successos occorridos em Portugal desde 1742 ate o anno de 1804. Lisboa: Typographia do Diário da Manhã, 1882.

HOF, Ulrich Im. A Europa no século das Luzes. Lisboa: Editorial Presença, 1995.

LISBOA, Amador Patrício de [FREIRE, Francico José]. Memorias das principaes providencias que se derão no terremoto que padeceo a Corte de Lisboa no anno de 1755. Lisboa, 1758.

LOPES, Maria Antónia. Mulheres, espaço e sociabilidade: a transformação dos papéis femininos em Portugual à luz de fontes literárias (segunda metade do século XVIII). Lisboa: Livros Horizonte, 1989.

MAXWELL, Kenneth. Marquês de Pombal: paradoxo do Iluminismo. Rio de Janeiro: Paz e Terra, 1996.

MELO, Sebastiāo José de Carvalho e. Memórias secretíssimas do marquês de Pombal e outros escritos. Mem Martins: Publicaçōes Europa-América, s/d.

Observaçôes secretíssimas do Marquês de Pombal sobre a collocação da Estatua Equestre de Sua Majestade o senhor D. José I. Gabinete Histórico, tomo XVII, Lisboa, p. 305-332, 1831.

MENDES, António Rosa. Ribeiro Sanches e o marquês de Pombal: intelectuais e poder no absolutismo esclarecido. Cascais: Patrimônia, 1998.

MONTEIRO, Nuno Gonçalo. D. José: na sombra de Pombal. Lisboa: Círculo de Leitores, 2006.

O Portugal de D. João V visto por três forasteiros. 2 ed. Lisboa: Biblioteca Nacional, 1989.

RATTON, Jacome. Recordaçôes de Jacome Ratton sobre ocorrências do seu tempo, de maio de 1747 a setembro de 1810. 2 ed. Coimbra: Editora da Universidade, 1920.

RODRIGUES, José Damião. "Para o socego e tranquilidade publica das ilhas": fundamentos, ambição e limites das reformas pombalinas nos Açores. Conferências e comunicações da VIa Jornada Setecentista. Curitiba: Aos Quatro Ventos; CEDOPE, 2006, p. 35-56.

SANTOS, Antonio Cesar de Almeida. Alguns princípios da política e da administração do reinado de D. José I (1750-1777). Textos da 26a Reunião da SBPH. Porto Alegre: SBPH, 2006, p. 01-15. Disponível em <http:// sbph.org/reuniao/26/trabalhos/Antonio\%20Cesar\%20Almeida\%20Santos.pdf>

Aritmética política e a administração do estado português na segunda metade do século XVIII. In: DORÉ, Andréa; SANTOS, Antonio Cesar de Almeida (Orgs.). Temas setecentistas: governos e populaçôes no Império português. Curitiba: UFPR; Fundação Araucária, 2009, p. 143-152.

. Observações sobre a teoria e a prática política pombalina: em busca da harmonia e consonância da sociedade civil. Anais da XXIV Reunião da SBPH. Curitiba: SBPH, 2005, p. 129-136.

Para viverem juntos em povoações bem estabelecidas: um estudo da política urbanística pombalina. Tese de Doutorado apresentada ao Programa de Pós-graduação em História da UFPR. Curitiba, 1999.

SENELLART, Michel. As artes de governar: do "regimen" medieval ao conceito de governo. São Paulo: Editora 34, 2006. SERRÃO, Joaquim Veríssimo. O marquês de Pombal: o homem, o diplomata e o estadista. 2.ed. Lisboa: s/ed., 1987. SERRÃO, José Vicente. O quadro económico. In: História de Portugal, v. 4 (O Antigo Regime, 1620-1807). Lisboa: Editorial Estampa, 1998, p. 67-109.

SILVA, Antonio de Moraes. Diccionario de lingua portuguesa. Rio de Janeiro: Officinas da S. A. Litho-Typographia Fluminense, 1922, 2v. 
SOARES, Luiz Carlos. A Albion revisitada no século XVIII: novas perspectivas para os estudos sobre a ilustração inglesa. Tempo, n. 16, p.175-206, 2004.

TAVARES, Rui. O pequeno livro do grande terramoto. $2^{a}$ ed. Lisboa: Tinta-da-China, 2005.

TEIXEIRA, Ivan. Mecenato pombalino e poesia neoclássica. São Paulo: Edusp, 1999.

VENTURI, Franco. Utopia e reforma no Iluminismo. Bauru: Edusc, 2003 [1970].

\section{RESUMO}

Neste artigo apresento algumas consideraçôes acerca da experiência portuguesa do Iluminismo, enfocando as mudanças realizadas (ou propostas) durante o reinado de D. José I. Como esse reinado ficou muito mais marcado pela figura do marquês de Pombal, Sebastiāo José de Carvalho e Melo, ao contrário de adotar uma perspectiva tradicional, que entende que essas mudanças não seguiram um plano previamente definido, defendo que as reformas ocorridas derivavam de uma "teoria" politica e formavam um plano de ação coerente, com o objetivo de fazer com que "um pequeno pais", Portugal, se igualasse a outros "em riqueza e em forças". Nesse aspecto, considero que tais mudanças, além de conterem referências a ideias de intelectuais portugueses da época, apresentam elementos que deixam manifesto o contato de Carvalho e Melo com doutrinas do direito natural, da política e de teor econômico, consoante "o ser e o agir de um estadista moderno".

Palavras-chave: Pombalismo, Antigo Regime, Iluminismo, Portugal, Século XVIII.

\section{ABSTRACT}

This article presents some considerations about the Portuguese experience of the Enlightenment, focusing on the changes made (or proposed) during the reign of King Joseph I. In a traditional perspective, the changes implemented by Sebastiāo José de Carvalho e Melo, Marquis of Pombal, did not follow a predetermined plan. I argue instead that the reforms that occurred stemmed from a "theory" and formed a political action plan consistent with the objective of making Portugal - a "small country" - equal to others "in wealth and strength". In this regard, I consider that such changes contain references to ideas of Portuguese intellectuals of the time and they present evidence indicating that Carvalho $e$ Melo had contact with the doctrines of natural law, politics and economic content, according to "the life and activity of a modern statesman".

Keywords: Pombalism, Ancient Regime, Enlightenment, Portugal, 18th Century. 